\title{
The Population Genetic Structure of Rhizoctonia solani AG-3PT from Potato in the Colombian Andes
}

\author{
Rosa L. Ferrucho, Paulo C. Ceresini, Ursula M. Ramirez-Escobar, Bruce A. McDonald, \\ Marc A. Cubeta, and Celsa García-Domínguez
}

First, third, and sixth authors: Facultad de Agronomía, Universidad Nacional de Colombia, Carrera 30 45-00 Bogotá, Colombia; second author: UNESP-Universidade Estadual Paulista, Campus de Ilha Solteira, Depto. de Fitossanidade, Engenharia Rural e Solos, 15385-000, Ilha Solteira, São Paulo, Brazil; fourth author: Institute of Integrative Biology-Plant Pathology, ETH Zurich, Zurich, Switzerland, 8092; and fifth author: Department of Plant Pathology, North Carolina State University, Raleigh 27695.

Accepted for publication 22 February 2013

\begin{abstract}
Ferrucho, R. L., Ceresini, P. C., Ramirez-Escobar, U. M., McDonald, B. A., Cubeta, M. A., and García-Domínguez, C. 2013. The population genetic structure of Rhizoctonia solani AG-3PT from potato in the Colombian Andes. Phytopathology 103:862-869.

The soilborne fungus Rhizoctonia solani anastomosis group 3 (AG3PT) is a globally important potato pathogen. However, little is known about the population genetic processes affecting field populations of $R$. solani AG-3PT, especially in the South American Colombian Andes, which is near the center of diversity of the two most common groups of cultivated potato, Solanum tuberosum and S. phureja. We analyzed the

genetic structure of 15 populations of $R$. solani AG-3PT infecting potato in Colombia using 11 simple-sequence repeat (SSR) markers. In total, 288 different multilocus genotypes were identified among 349 fungal isolates. Clonal fractions within field populations were 7 to $33 \%$. $\mathrm{R}_{\mathrm{ST}}$ statistics indicated a very low level of population differentiation overall, consistent with high contemporary gene flow, though moderate differentiation was found for the most distant southern populations. Genotype flow was also detected, with the most common genotype found widely distributed among field populations. All populations showed evidence of a mixed reproductive mode, including both asexual and sexual reproduction, but two populations displayed evidence of inbreeding.
\end{abstract}

The basidiomycetous fungus Rhizoctonia solani Kühn anastomosis group 3 (AG-3PT) (teleomorph = Thanatephorus cucumeris (A. B. Frank) Donk) is a soilborne plant pathogen that can infect potato (Solanum tuberosum L.) and other solanaceous crops, including eggplant, pepper, and tomato $(5,62)$. Infection of potato often occurs early in the growing season and results in killing of sprout tips and the development of cankers on stems $(2,21,31)$. The disease delays and reduces the emergence of plants and decreases the number of stems. As the plant matures, stolons can be infected, resulting in the production of deformed tubers of reduced quality and market value (31). At the end of the growing season when the plants begin to senesce, the fungus forms black sclerotia (the black scurf phase of the disease) on the surface of daughter tubers (5). The fungus overwinters as mycelia and sclerotia in diseased plant tissue, in soil, and on tubers $(2,5,21$, 35,46 ). The sexual stage (forming basidia and basidiospores) can form during periods of high relative humidity at the base of potato stems in the plant canopy $(35,62)$. However, the importance of sexual spores in the disease cycle of $R$. solani AG-3PT is not well understood.

Though $R$. solani AG-3PT is described as having a predominantly asexual lifestyle associated with the production of mycelia and sclerotia as the primary structures for dispersal and survival $(13,14)$, population genetic studies reported variable $R$. solani AG-3PT populations that were not highly clonal $(4,11,36)$. Field studies needed to determine the role of sexual reproduction

Corresponding author: P. C. Ceresini;

E-mail address: paulo.ceresini@ @io.feis.unesp.br

* The $\boldsymbol{e}$-Xtra logo stands for "electronic extra" and indicates that the online version contains two supplementary tables.

http://dx.doi.org/10.1094/PHYTO-11-12-0278-R

(C) 2013 The American Phytopathological Society (implying a role for basidiospores) in the disease cycle are lacking. A population genetic study of five geographical populations of $R$. solani AG-3PT from eastern North Carolina found no subdivision, suggesting that long-distance gene flow was occurring (11). The lack of population differentiation was postulated to be a consequence of continuous introduction of tuber-borne inoculum from Canada and the northern United States into commercial potato-production fields in North Carolina (9-11).

There have been no studies on the population genetics of $R$. solani AG-3PT in South America, a region that is thought to be the center of origin for potato $(7,56)$ and, possibly, of potato pathogens (27). Various researchers have proposed that potato plants were domesticated by the Bolivian natives in the region located between lakes Titicaca and Poopó $(39,47,56)$ and subsequently dispersed throughout South America. The pre-Hispanic Muisca or Chibcha peoples living in the cold highlands of central Colombia cropped potato (named yomsa or yomuy) beginning 1,200 to 1,500 years ago $(44,50)$. The potato was introduced into Europe from South America in $1567(3,47)$. However, it was only after 1850 that potato became an important crop in the Colombian highlands (39) and a major agricultural commodity for export (52). The modern Colombian potato varieties originated from Colombian potato germplasm and were developed through local breeding efforts $(16,22,61)$.

In Colombia, as in most of South America's potato-growing regions, $R$. solani AG-3PT is the most widespread soilborne pathogen affecting the two most common groups of potato, $S$. tuberosum L. and S. phureja (Juz. \& Bukasov) Hawkesand (19). Seed tubers infested with mycelium and sclerotia of $R$. solani likely contribute to the widespread occurrence and dissemination of the pathogen in the region $(5,23)$. The use of seed tubers certified to be free of $R$. solani could reduce long-distance dispersal of the pathogen; however, current phytosanitary regulations allow $\leq 10 \%$ infestation of seed potato (33). Seed tubers are not 
imported into Colombia, except in Departments close to Ecuador and Venezuela that are also in the Andes (16,33). Thus, the introduction of $R$. solani AG-3 on infected potato tubers from outside of Colombia is expected to be rare. An integrated approach including cultural, chemical, and biological control practices (5) is needed to manage this disease. In Colombia, only three fungicides (thifluzamide and the mixture of carboxin + captan) are currently labeled for managing this disease on seed potato (34). There are no resistant varieties currently available, although earlier studies reported potato germplasm with differential responses to $R$. solani AG-3PT (8).

Despite the relative importance of black scurf and stem canker disease in Colombia, the pathogen biology remains poorly understood and questions related to the genetic diversity and structure of $R$. solani AG-3PT populations remain unanswered. The primary objective of this study was to ascertain the population genetic structure of potato-infecting $R$. solani AG-3PT from the Colombian Andes using recently developed simple-sequence repeat (SSR) genetic markers (20). The first objective was to determine whether populations were genetically subdivided or exhibited significant gene flow. Based on earlier findings described above, our null hypothesis was that there is no subdivision among geographical populations of $R$. solani AG-3 PT. The second objective was to determine whether the genetic structure in Colombia was consistent with a recombining population. Our null hypothesis was that populations would exhibit a mixed reproductive system characterized by random mating and local dispersal of a small number of clones. An alternative hypothesis was that populations would be largely asexual, with a few highly successful clones that are widely distributed across Colombia.

\section{MATERIALS AND METHODS}

Population sampling, fungal isolation, and DNA extraction. Seven major potato-producing Departments in Colombia were sampled: Nariño and Cauca in the south, Antioquia in the west, Cundinamarca and Boyacá in the center, and Santander and Norte de Santander in the north (Table 1; Fig. 1). These Departments are responsible for approximately $85 \%$ of the potato production in Colombia (16). The sampling strategy was to obtain sympatric pairs of field populations from each county sampled in each Department. In three counties (Sibate, Carcasí, and Chitagá), it was not possible to obtain enough isolates from one of the paired fields to allow a meaningful comparison between fields within a county. But in six counties, we obtained complete paired collections. Naturally infected 2- to 3-month-old potato plants exhibiting symptoms of stem canker were sampled from 5 fields in
Cundinamarca, 4 fields in Boyacá, 2 fields in Antioquia, 2 fields in Nariño, 1 field in Santander, and 1 field in Norte de Santander, generating a total of 15 field populations (Table 1). In each field, transect sampling was used to collect 20 to 35 symptomatic plants. Seven transects were spaced $10 \mathrm{~m}$ apart, with five plants separated by 5 to $10 \mathrm{~m}$ sampled along each transect. From 10 field populations, we obtained 54 isolates from potato seed tubers (Table 2) to determine the genotype diversity associated with seedborne inoculum. We also included three populations of $R$. solani AG-3 from $S$. phureja, which is an important native diploid potato with a low level of domestication that is historically cropped in the area $(22,61)$. Detailed field histories were not available but potato growers in the sampled areas generally rotate potato crops with pasture grasses which are not hosts for $R$. solani AG-3 (19).

Isolations were made by transferring fragments of infected stems or sclerotia to petri plates containing selective media (37) and incubating at $20^{\circ} \mathrm{C}$ in the dark. Hyphal tips from 1- or 2-dayold colonies were transferred to potato dextrose agar (PDA) (Oxoid Ltd., Hampshire, UK). Sclerotia from 25-day-old cultures growing on PDA plates were transferred to $1.8-\mathrm{ml}$ cryotubes (Nunc CryoLine System, Roskilde, Denmark) containing anhydrous silica gel for long-term storage at $4^{\circ} \mathrm{C}$. Stored sclerotia were used to initiate new cultures as required.

Mycelia for genomic DNA extraction were obtained from 5-day-old cultures on PDA containing a sterile cellophane membrane on top. After incubation at room temperature, mycelium was scraped from the cellophane membrane, then frozen and lyophilized. DNA was extracted from lyophilized mycelium with the DNeasy Plant Mini-Kit (Qiagen, Hilden, Germany). The anastomosis grouping of $R$. solani isolates was determined by polymerase chain reaction (PCR) using AG-3PT-specific primers for the internal transcribed spacer $5.8 \mathrm{~S}$ region of the ribosomal DNA (38).

SSR genotyping. Isolates were genotyped using 11 polymorphic SSR loci using fluorescent-labeled primers (20). PCR conditions for all loci were those used by Ferrucho et al. (20), except for a final extension cycle of $30 \mathrm{~min}$ at $72^{\circ} \mathrm{C}$. For fragment analyses, 1 to $2 \mu \mathrm{l}$ of fluorescent-labeled PCR products were mixed and electrophoresed using an ABI PRISM 3100 (Applied Biosystems) automated sequencer at the Genetic Diversity Center of ETH Zurich along with a fluorescent-labeled size standard (GeneScan-500 LIZ; Applied Biosystems, Foster City, CA). Isolate RH002 (from tuber-borne sclerotia) was included as a positive control in every run of 94 samples. Additionally, we repeated the genotyping of population Cogua2, one of the two populations used for developing the SSR markers (20). Isolates from Boyacá,

TABLE 1. Description of the field populations of Rhizoctonia solani anastomosis group 3PT sampled from potato in the Colombian Andes that were included in this study

\begin{tabular}{|c|c|c|c|c|c|c|c|c|}
\hline Department & County & $\begin{array}{l}\text { Population } \\
\text { name }\end{array}$ & Latitude & Longitude & $\begin{array}{l}\text { Altitude } \\
\text { (masl) }\end{array}$ & $\begin{array}{l}\text { Linear distance } \\
(\mathrm{km})\end{array}$ & Potato cultivar & $\begin{array}{l}\text { Sampling } \\
\text { year }\end{array}$ \\
\hline \multirow[t]{5}{*}{ Cundinamarca } & \multirow[t]{2}{*}{ Subachoque } & Subachoque1 & $4^{\circ} 57^{\prime} 26.00^{\prime \prime} \mathrm{N}$ & $74^{\circ} 11^{\prime} 59.00^{\prime \prime} \mathrm{W}$ & 2931 & 0 & $\begin{array}{l}\text { Solanum tuberosum 'Diacol } \\
\text { capiro' }\end{array}$ & 2006 \\
\hline & & Subachoque2 & $4^{\circ} 57^{\prime} 11.00^{\prime \prime} \mathrm{N}$ & $74^{\circ} 12^{\prime} 56.00^{\prime \prime} \mathrm{W}$ & 3095 & 2.3 & S. tuberosum 'Diacol capiro' & 2006 \\
\hline & \multirow[t]{3}{*}{ Cogua } & Cogua1 & $5^{\circ} 04^{\prime} 32.00^{\prime \prime} \mathrm{N}$ & $73^{\circ} 58^{\prime} 33.00^{\prime \prime} \mathrm{W}$ & 2730 & 28.0 & S. phureja & 2006 \\
\hline & & Cogua2 & $5^{\circ} 04^{\prime} 22.00^{\prime \prime} \mathrm{N}$ & $73^{\circ} 58^{\prime} 45.00^{\prime \prime} \mathrm{W}$ & 2722 & 27.4 & S. phureja & 2006 \\
\hline & & Sibate & $4^{\circ} 25^{\prime} 16.00^{\prime \prime} \mathrm{N}$ & $74^{\circ} 14^{\prime} 56.00^{\prime \prime} \mathrm{W}$ & 3296 & 59.3 & S. tuberosum 'Parda pastusa' & 2006 \\
\hline \multirow[t]{2}{*}{ Nariño } & \multirow[t]{2}{*}{ Pasto } & Pasto1 & $1^{\circ} 8^{\prime} 41.50^{\prime \prime} \mathrm{N}$ & $77^{\circ} 20^{\prime} 29.29^{\prime \prime} \mathrm{W}$ & 3095 & 558.0 & S. tuberosum 'Parda pastusa' & 2007 \\
\hline & & Pasto2 & $1^{\circ} 8^{\prime} 16.74^{\prime \prime} \mathrm{N}$ & $77^{\circ} 18^{\prime} 37.91^{\prime \prime} \mathrm{W}$ & 3084 & 546.0 & S. tuberosum 'Parda pastusa' & 2007 \\
\hline \multirow[t]{2}{*}{ Antioquia } & \multirow[t]{2}{*}{ La Unión } & LaUnion1 & $5^{\circ} 58^{\prime} 22.00^{\prime \prime} \mathrm{N}$ & $75^{\circ} 22^{\prime} 59.00^{\prime \prime} \mathrm{W}$ & 2505 & 172.1 & S. tuberosum 'Diacol capiro' & 2008 \\
\hline & & LaUnion2 & $6^{\circ} 00^{\prime} 26.00^{\prime \prime} \mathrm{N}$ & $75^{\circ} 21^{\prime} 40.00^{\prime \prime} \mathrm{W}$ & 2504 & 173.5 & S. tuberosum 'Diacol capiro' & 2008 \\
\hline \multirow[t]{4}{*}{ Boyacá } & \multirow[t]{2}{*}{ Ventaquemada } & Ventaquemada1 & $5^{\circ} 23^{\prime} 30.40^{\prime \prime} \mathrm{N}$ & $73^{\circ} 27^{\prime} 49.10^{\prime \prime} \mathrm{W}$ & 2918 & 95.3 & S. tuberosum 'Parda pastusa' & 2007 \\
\hline & & Ventaquemada2 & $5^{\circ} 25^{\prime} 00.20^{\prime \prime} \mathrm{N}$ & $73^{\circ} 27^{\prime} 25.30^{\prime \prime} \mathrm{W}$ & 2907 & 97.3 & S. tuberosum 'ICA única' & 2009 \\
\hline & \multirow[t]{2}{*}{ Soraca } & Soraca1 & $5^{\circ} 30^{\prime} 09.00^{\prime \prime} \mathrm{N}$ & $73^{\circ} 20^{\prime} 22.09^{\prime \prime} \mathrm{W}$ & 2809 & 114.0 & S. phureja & 2007 \\
\hline & & Soraca2 & $5^{\circ} 30^{\prime} 45.00^{\prime \prime} \mathrm{N}$ & $73^{\circ} 19^{\prime} 33.00^{\prime \prime} \mathrm{W}$ & 2849 & 112.6 & S. tuberosum 'Diacol capiro' & 2009 \\
\hline Santander & Carcasí & Carcasí & $6^{\circ} 04^{\prime} 47.00^{\prime \prime} \mathrm{N}$ & $72^{\circ} 33^{\prime} 01.81^{\prime \prime} \mathrm{W}$ & 3296 & 261.0 & S. tuberosum 'Parda pastusa' & 2008 \\
\hline Norte de Santander & Chitagá & Chitagá & $7^{\circ} 03^{\prime} 06.20^{\prime \prime} \mathrm{N}$ & $72^{\circ} 40^{\prime} 06.38^{\prime \prime} \mathrm{W}$ & 2989 & 286.0 & S. tuberosum 'Parda pastusa' & 2008 \\
\hline
\end{tabular}

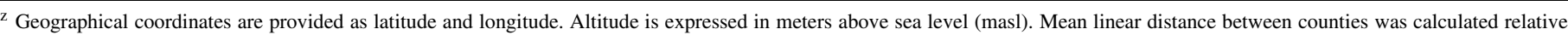
to the field Subachoque1. Distances ranged from $0.5 \mathrm{~km}$ between fields in the same county to $840 \mathrm{~km}$ between fields from the two most distant Departments. 
Santander, and Norte de Santander Departments were processed in the Institute of Genetics of the Universidad Nacional de Colombia. The PCR conditions were as described previously. For fragment analyses, we used an ABI PRISM 3500 (Applied Biosystems) automated sequencer. Isolate RH002 was also included as a positive control in every run of 94 samples. As controls, 15 isolates genotyped at ETH were included in the fragment analysis conducted in Colombia. Statistical binning of the alleles was conducted using the software GeneMapper version 4.0 (Applied Biosystems).

Data analysis. SSR information content. Though it is dikaryotic, $R$. solani AG-3PT was treated as a functional diploid for all analyses, and all data were consistent with this assumption $(11,36)$. The first analysis for the 11 SSR loci determined the range of repeats for each locus (Supplementary Table 1), the total and the average number of alleles per locus and per sampled field, and the identification of private alleles (i.e., those present in only one population) using allele frequency data computed by the program CONVERT version 1.31 (26).

Genotype diversity. Each isolate was assigned to a multilocus microsatellite genotype (MLMG) using GENODIVE (43). Isolates with the same MLMG were treated as clones. Indices of clonal diversity were calculated as follows: (i) number of MLMGs per population; (ii) site-specific MLMGs; (iii) clonal fraction or the proportion of isolates originating from asexual reproduction, calculated as 1 - (number of different MLMGs)/(total number of isolates) (65); (iv) Stoddart and Taylor's genotypic diversity, calculated as $G_{0}=1 / \Sigma p i 2$, where $p i$ is the frequency of the $i$ th genotype (59); and (v) evenness, as an indicator of how the genotypes are distributed within the population $\left(G_{0}\right.$ scaled by the maximum number of expected genotypes) (29). Comparisons for differences in clonal diversity indices among pairs of populations were performed using a pairwise bootstrap test (40) using 1,000 permutations, with subsampling to match the size of the smallest population (29). Finally, we performed the clone correction, selecting only one individual of each MLMG to perform subsequent analyses.

Gene diversity and population differentiation. Allelic richness and expected heterozygosity were calculated as indexes of gene diversity using the program FSTAT 2.9.3.2 (28). Nei's unbiased gene diversity or expected heterozygosity was estimated as $n /(n-$ 1) $\times\left(1-\Sigma_{i} p_{i}{ }^{2}\right)$, where $p$ is the observed frequency of the $i$ th allele and $n$ is the sample size (45). Allelic richness was estimated as the mean number of alleles per locus (15) for a standardized sample size of eight individuals, using rarefaction (32), as described previously (48). Finally, we tested whether pairs of populations differed for allelic richness and gene diversity with FSTAT version 2.9.3.2 using bootstrapping based on 1,000 permutations.

The distribution of gene diversity was evaluated using hierarchical analysis of molecular variance (AMOVA) (18). $F$ statistics were calculated to quantify differentiation between pairs of populations and to assess the degree of population subdivision, based on the sum of squared size differences for SSR loci $\left(R_{\mathrm{ST}}\right)$ (55). The null distribution of pairwise $F$ statistics values under the hypothesis of no differentiation between two populations was obtained by permutating haplotypes between populations. Genetic differentiation between populations was considered significant when $P \leq 0.05$. AMOVA was used to partition the covariance components due to among group (Departments), among-populations-within-group, and within-population effects. Significance of the $F$ statistics was tested using 10,100 permutations by a nonparametric approach (18) using the program ARLEQUIN version 3.11 (17)

Reproductive mode: Hardy-Weinberg equilibrium and multilocus associations. To assess the contribution of sexual recombination to population structure, tests of Hardy-Weinberg Equilibrium (HWE) and multilocus association were performed. Tests for HWE were performed for each locus within each population with the program ARLEQUIN 3.11. This test is analogous to Fisher's exact test on a two-by-two contingency table but extended to a contingency table of arbitrary size $(30,49)$. $P$ values were obtained using a Markov Chain Monte Carlo (MCMC) approach, generating an exact probability distribution not biased by rare alleles or low sample size (49). The inbreeding coefficient $\left(F_{\mathrm{IS}}\right)$ across loci was calculated to test for a significant deficit or excess of heterozygotes when compared with HWE expectations (63), based on 10,100 permutations using the program ARLEQUIN 3.11.

The hypothesis of independence among alleles at distinct pairs of loci was tested using Fisher's exact test (25) based on an MCMC algorithm (with 10,000 batches and 10,000 iterations per batch) (49) and implemented in GENEPOP (49) version 3.4. To avoid type I error, the significance levels were adjusted using the Bonferroni correction (51). The multilocus index of association
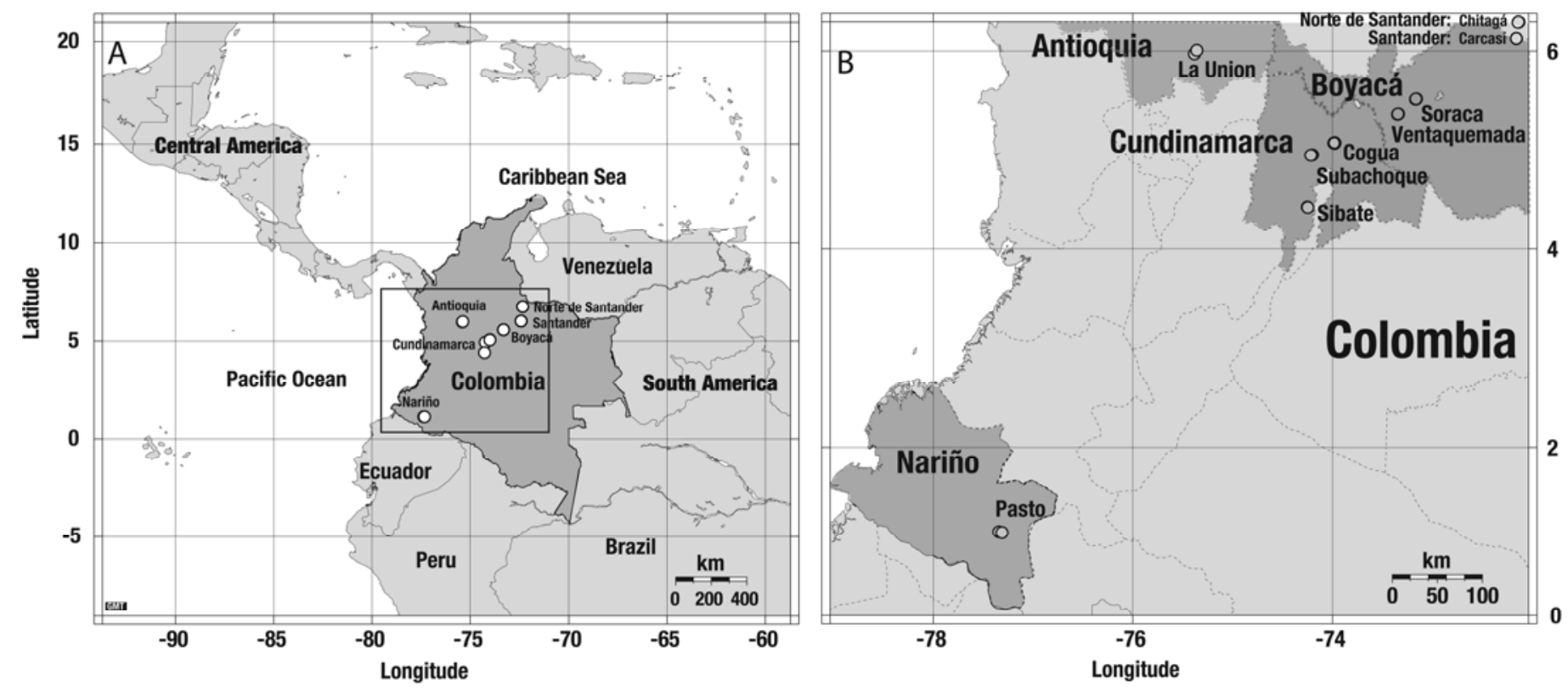

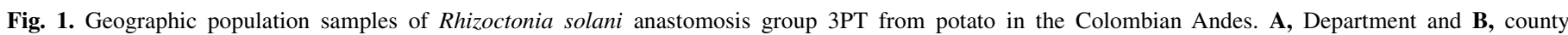
populations. The latitude (north-south) and longitude (west-east) values are indicated on the maps. 
$\left(I_{\mathrm{A}}\right)(41)$ and $\bar{r}_{\mathrm{D}}$ (an alternative measure of $I_{\mathrm{A}}$ ) were tested for significance with 10,000 randomizations (1). These tests are implemented in MULTILOCUS version 1.3 (1). An $I_{\mathrm{A}}$ significantly different from zero indicates linkage disequilibrium. $\bar{r}_{\mathrm{D}}$ is a modified measure of $I_{\mathrm{A}}$, adjusted for the number of loci. This index ranges from zero, when there is no disequilibrium, to one, when there is disequilibrium among tested loci.

\section{RESULTS}

SSR information content, gene and genotype diversity. Eleven SSR loci were used to characterize the genetic structure of 15 populations of $R$. solani AG-3PT from the Colombian Andes. The SSR datasets were collected in two different laboratories, using different supplies and also two different automated fragment analyzers. The allele size data obtained for 15 control isolates and for population Cogua2 in the two laboratories were consistent, showing that the SSR markers were repeatable and reproducible between laboratories.

All SSR loci were polymorphic in all populations, except for TC_AG3_8, which was monomorphic in two populations (Subachoque2 and Pasto1). The number of alleles at each locus ranged from 2 (TC_AG3_0) to 14 (TC_AG3_16), with an average of 9 alleles per locus. The overall allelic richness across populations was 3.8. Nei's unbiased gene diversity was 0.56 to 0.65 across populations (Table 2). In total, 21 private alleles were found in 10 populations (Table 2).

We identified 288 MLMGs among the 349 isolates analyzed (Table 2). All 288 MLMGs were heterozygous for at least 1 of the 11 loci examined. In total, 246 individuals $(85 \%$ of the population) were heterozygous for more than five loci, while 19 individuals (6.5\% of the population) were heterozygous for nine loci. There were no significant differences between pairs of populations for either genotypic diversity or evenness. Low clonal frac- tions were observed in most populations, with the highest clonal fractions found in Ventaquemada2 (0.29) and Subachoque2 (0.33). In total, 33 MLMGs representing 80 isolates were shared among field populations. Although MLMG 1 was sampled 11 times from distinct populations (this clone was found once in population Subachoque1, twice in Subachoque2 and Cogua2, and three times in La Unión1 and La Unión2), clones of most MLMGs were distributed mainly within the same field or county. Population Subachoque1 shared the largest number of MLMGs (11 of 23 isolates). Using the Psex-value test statistic (57), we calculated the likelihood of observing MLMG 1 more than once across these five populations as a result of independent assortment of alleles following sexual reproduction. The Psex statistic was $4.27^{-79}$, making it highly unlikely that this shared genotype emerged independently in each population as a result of sexual reproduction.

Comparisons between pairs of isolates collected from different stems in the same plant showed that most of them (67\% of the 36 pairs tested) represented a different MLMG, indicating that a single plant is often infected by more than one genotype of this pathogen. Comparing isolates obtained from stems and seed tubers from the same plant revealed that only $18 \%$ of the 56 pairs tested were clones, providing evidence for multiple infections on potato stems and seed tubers, which can be due to the distinct nature of the inoculum, either soil- or even seed-tuber-borne.

Population differentiation. AMOVA showed that variation among Departments and among fields within Departments each represented $<1 \%$ of the total variance. In contrast, the variation within fields accounted for $94 \%$ of the total variance (Table 3). Pairwise analyses of population differentiation showed that most of the populations were very similar. There was no evidence for population differentiation between years. Among 104 pairwise comparisons, 22 were significantly differentiated $(P \leq 0.05)$. Five of these pairs showed low differentiation $\left(R_{\mathrm{ST}}<0.05\right)$ while 17 pairs were moderately differentiated $\left(R_{\mathrm{ST}}\right.$ of 0.05 to 0.15$)$ (Sup-

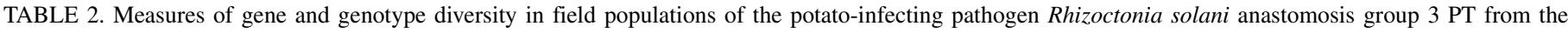
Colombian Andes

\begin{tabular}{|c|c|c|c|c|c|c|c|c|c|c|c|}
\hline State, population & $\begin{array}{l}\text { Stems } \\
(N)\end{array}$ & $\begin{array}{c}\text { Tubers } \\
(N)\end{array}$ & $\begin{array}{l}\text { Total } \\
(N)^{\mathrm{s}}\end{array}$ & $\begin{array}{c}\text { Genotypes } \\
(N)\end{array}$ & $\begin{array}{l}\text { Site-specific } \\
\text { genotypes }^{t}\end{array}$ & $\begin{array}{l}\text { Clonal } \\
\text { fraction }\end{array}$ & $\begin{array}{l}\text { Stoddart's } \\
G_{\mathrm{o}}{ }^{\mathrm{u}}\end{array}$ & Evenness $^{\mathrm{v}}$ & $H_{\mathrm{e}}^{\mathrm{w}, \mathrm{x}}$ & $\begin{array}{c}\text { Allelic } \\
\text { richness } \\
\text { x,y }\end{array}$ & $\begin{array}{c}\text { Private } \\
\text { alleles }(N)^{\mathrm{z}}\end{array}$ \\
\hline \multicolumn{12}{|l|}{ Cundinamarca } \\
\hline Subachoque1 & 17 & 11 & 28 & 23 & $12(11)$ & 0.18 & 19.60 & 0.85 & $0.62 \mathrm{a}$ & $3.65 \mathrm{~b}$ & 0 \\
\hline Subachoque2 & 12 & 6 & 18 & 12 & $5(7)$ & 0.33 & 10.10 & 0.84 & $0.62 \mathrm{a}$ & $3.56 \mathrm{~b}$ & 0 \\
\hline Cogua1 & 20 & 3 & 23 & 21 & $17(4)$ & 0.09 & 19.60 & 0.93 & 0.64 a & $4.17 \mathrm{a}$ & 3 \\
\hline Cogua2 & 23 & 11 & 34 & 27 & $20(7)$ & 0.21 & 22.20 & 0.82 & $0.62 \mathrm{a}$ & $3.79 \mathrm{~b}$ & 2 \\
\hline Sibate & 26 & 7 & 33 & 28 & $23(5)$ & 0.15 & 25.30 & 0.90 & 0.63 a & $4.28 \mathrm{a}$ & 3 \\
\hline \multicolumn{12}{|l|}{ Nariño } \\
\hline Pasto1 & 18 & 0 & 18 & 17 & $16(1)$ & 0.06 & 16.20 & 0.95 & $0.57 \mathrm{~b}$ & $3.63 \mathrm{~b}$ & 1 \\
\hline Pasto2 & 22 & 0 & 22 & 19 & $16(3)$ & 0.14 & 16.10 & 0.85 & $0.56 \mathrm{~b}$ & $3.73 \mathrm{~b}$ & 1 \\
\hline \multicolumn{12}{|l|}{ Antioquia } \\
\hline La Unión1 & 17 & 0 & 17 & 14 & $9(5)$ & 0.18 & 11.60 & 0.83 & $0.64 \mathrm{a}$ & $3.82 \mathrm{~b}$ & 1 \\
\hline La Unión2 & 33 & 2 & 35 & 28 & $21(7)$ & 0.20 & 24.00 & 0.86 & $0.62 \mathrm{a}$ & $3.88 \mathrm{~b}$ & 4 \\
\hline \multicolumn{12}{|l|}{ Boyacá } \\
\hline Soraca1 & 21 & 1 & 22 & 18 & $14(4)$ & 0.18 & 16.10 & 0.90 & $0.57 \mathrm{~b}$ & $3.75 \mathrm{~b}$ & 0 \\
\hline Soraca2 & 22 & 1 & 23 & 17 & $11(6)$ & 0.26 & 12.90 & 0.76 & 0.63 a & $4.08 \mathrm{a}$ & 2 \\
\hline Ventaquemada1 & 20 & 0 & 20 & 17 & $14(3)$ & 0.15 & 15.40 & 0.91 & $0.58 \mathrm{a}$ & $3.84 \mathrm{~b}$ & 0 \\
\hline Ventaquemada2 & 21 & 0 & 21 & 15 & $10(5)$ & 0.29 & 13.40 & 0.89 & $0.58 \mathrm{~b}$ & $3.40 \mathrm{c}$ & 0 \\
\hline \multicolumn{12}{|l|}{ Santander } \\
\hline Carcasí & 12 & 9 & 21 & 19 & $13(6)$ & 0.10 & 16.30 & 0.86 & 0.65 a & $4.00 \mathrm{a}$ & 3 \\
\hline \multicolumn{12}{|l|}{ Norte de Santander } \\
\hline Chitagá & 11 & 3 & 14 & 13 & 7 (6) & 0.07 & 12.30 & 0.94 & $0.56 \mathrm{~b}$ & $3.46 \mathrm{c}$ & 1 \\
\hline Overall & 295 & 54 & 349 & 288 & $208(80)$ & 0.17 & 16.74 & 0.87 & 0.61 & 3.80 & 21 \\
\hline
\end{tabular}

s Population sample size.

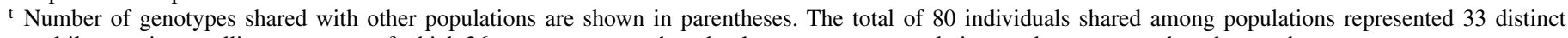
multilocus microsatellite genotypes, of which 26 genotypes were shared only once among populations and seven were shared more than once.

u Stoddart and Taylor's genotypic diversity $(58,59)$.

v $G_{\mathrm{o}}$ scaled by the maximum number of expected genotypes; an evenness value $=1.0$ indicates that all genotypes have equal frequencies.

w Nei's unbiased gene diversity (45), also known as expected heterozygosity, averaged over all loci, corrected for sample size.

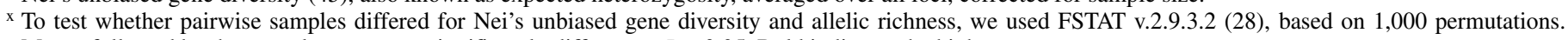
Means followed by the same letter are not significantly different at $P \leq 0.05$. Bold indicates the highest means.

y Calculated according to El Mousadik and Petit (15), with subsampling to match the sample size of the smallest population.

z Alleles occurring in only one population, determined with Convert 1.31 (26). 
plementary Table 2). Populations in close geographical proximity ( 0.3 to $3.0 \mathrm{~km}$ distant from one another) had $R_{\mathrm{ST}}$ values close to zero. Populations located in southern Colombia (Nariño Department) were differentiated from populations sampled in Cundinamarca, Boyacá, Santander, and Norte de Santander Departments, which were 550 to $840 \mathrm{~km}$ apart. Pooling field populations from the same county into single-county populations supported previous results (Table 4). Pooling different county populations into Departments indicated that the most southern populations (Nariño Department) were genetically differentiated from the northern (Santander and Norte de Santander) and from the central (Cundinamarca and Boyacá) Departments. We found evidence for isolation by distance when comparing pairwise genetic distances $[\Phi S T /(1-\Phi S T)]$ and geographical distances $[\ln (D+1)$, where $D=$ average distance between Departments, in $\mathrm{km}]$. The regression between genetic distances $(Y)$ and geographical distances $(X)$ was significant at $P=0.004\left(Y=-0.0302+0.0078 X ; R^{2}=0.41\right)$ (Fig. 2). Populations of $R$. solani AG-3 from $S$. phureja and $S$. tuberosum were not significantly differentiated.

Reproductive mode: HWE and multilocus associations. The exact test for HWE showed that an average of $78 \%$ of loci were in HWE in the local populations (Table 5). Pastol deviated from HWE expectations in 4 of 10 loci examined. This population also showed a significant $F_{\text {IS }}$ value $(0.25, P=0.02)$. A similar trend was observed for Soraca2, with four loci deviating from HWE and a $F_{\text {IS }}$ value of $0.28(P=0.01)$, which is consistent with in- breeding. $F_{\text {IS }}$ values were nonsignificant for the remaining 13 populations. The overall $F_{\text {IS }}$ value was $0.042(P=0.076)$. Locus TC_AG3_10 deviated from $\mathrm{HWE}$ in 8 populations while TC_AG3_9 and TC_AG3_6 deviated from HWE in 6 of 15 populations. Deviations from HWE were associated with a deficiency of heterozygotes in these populations.

Multilocus gametic equilibrium indices $I_{\mathrm{A}}$ and $\bar{r}_{\mathrm{D}}$ were significantly different from zero $(P \leq 0.001)$ for 10 of 15 populations $\left(I_{\mathrm{A}}\right.$ of 0.33 to 1.39 and $\bar{r}_{\mathrm{D}}$ of 0.034 to 0.14 ) (Table 5). However, only three populations showed $>10 \%$ of locus pairs in disequilibrium: Subachoque1 (16.3\%), Cogua2 (25.4\%), and LaUnión2 (14.5\%).

\section{DISCUSSION}

This is the first comprehensive study describing the genetic structure of potato-infecting populations of $R$. solani AG-3PT from cropping areas close to the putative center of origin of potato. Our sampling strategy included the most important potatoproducing areas in the Colombian Andes. Comparisons were made between pairs of sympatric populations to understand the extent and distribution of genetic variation within counties and among more distant regional populations.

We hypothesize that gene and genotype flow make significant contributions to the population structure of this pathogen. Our results showed either no or very low pairwise population subdivision, consistent with significant gene flow among populations

TABLE 3. Hierarchical distribution of gene diversity among field populations of Rhizoctonia solani anastomosis group 3PT sampled from diseased potato in the Colombian Andes ${ }^{\mathrm{z}}$

\begin{tabular}{|c|c|c|c|c|c|c|}
\hline \multirow[b]{2}{*}{ Source of variation } & \multicolumn{6}{|c|}{ Distance method: sum of squared size differences $\left(R_{\mathrm{ST}}\right)$} \\
\hline & df & Sum of squares & Variance components & Variation $(\%)$ & Fixation indices & $P$ value \\
\hline Among Departments & 4 & 599.6 & 0.61 & 0.99 & $F_{\mathrm{CT}}=0.0099$ & 0.079 \\
\hline Among populations within Departments & 10 & 833.7 & 0.52 & 0.84 & $F_{\mathrm{SC}}=0.0085$ & 0.110 \\
\hline Among individuals within populations & 273 & $17,379.4$ & 2.85 & 4.59 & $F_{\mathrm{IS}}=0.0468$ & 0.076 \\
\hline Within individuals & 288 & $16,695.0$ & 57.97 & 93.58 & $F_{\mathrm{IT}}=0.0642$ & 0.025 \\
\hline Total & 575 & $35,507.7$ & 61.95 & $\ldots$ & $\ldots$ & $\ldots$ \\
\hline
\end{tabular}

${ }^{\mathrm{z}}$ Analysis of molecular variance performed using the program ARLEQUIN version 3.11 (18). Distance method based on the sum of squared size differences $\left(R_{\mathrm{ST}}\right)$ between two haplotypes for microsatellite data, according to Slatkin (55) Number of permutations $=10,100$. Groups correspond to the Departments sampled. Santander and Norte de Santander were pooled into a single group. $P$ values show the probability of having, by chance alone, a more extreme variance component than the observed values.

TABLE 4. Fixation indices $\left(R_{\mathrm{ST}}\right)$ for pairwise comparisons between counties' or Departments' populations of Rhizoctonia solani anastomosis group 3PT sampled from diseased potato in the Colombian Andes ${ }^{\mathrm{x}}$

\begin{tabular}{|c|c|c|c|c|}
\hline Contrasts & & & $R_{\mathrm{ST}^{\mathrm{y}}}$ & $P$ value \\
\hline \multicolumn{5}{|l|}{ Between counties $^{\mathrm{z}}$} \\
\hline Sibate & versus & Subachoque (Cundinamarca) & 0.0375 & 0.016 \\
\hline \multicolumn{5}{|l|}{ Nariño } \\
\hline Pasto & versus & Subachoque (Cundinamarca) & 0.0712 & 0.001 \\
\hline Pasto & versus & Cogua (Cundinamarca) & 0.0390 & 0.000 \\
\hline Pasto & versus & Soraca (Boyacá) & 0.0496 & 0.003 \\
\hline Pasto & versus & Carcasí (Santander) & 0.0901 & 0.000 \\
\hline Pasto & versus & Chitagá (Norte de Santander) & 0.0436 & 0.044 \\
\hline \multicolumn{5}{|c|}{ Between Departments } \\
\hline Cundinamarca & versus & Nariño & 0.024 & 0.033 \\
\hline Cundinamarca & versus & Boyacá & 0.001 & 0.345 \\
\hline Cundinamarca & versus & Antioquia & 0.001 & 0.380 \\
\hline
\end{tabular}

${ }^{\mathrm{x}}$ For between-county comparisons, the two field populations from the same county were pooled. For between-Departments comparisons multiple county populations were pooled. Distances were computed as the sum of squared size differences between two haplotypes, for microsatellite data (55).

y Values in bold are significant at $P \leq 0.05$.

${ }^{\mathrm{z}}$ Only pairs of populations with significantly different $R_{\mathrm{ST}}$ are presented. $P$ value calculated based on 10,100 permutations using the program ARLEQUIN version 3.11 . 
in the Colombian Andes. Lack of population subdivision was previously reported for populations of AG-3PT sampled in the southern United States and Denmark $(11,36)$. The human-mediated movement of infested seed potato was postulated as the most plausible cause of this low differentiation because $R$. solani AG3PT is efficiently dispersed on seed potato (54). Although approximately 30 potato varieties are recommended by the Colombian agricultural extension services, only 5 are commonly cultivated: Diacol capiro, Parda pastusa, Criolla ( $S$. phureja), Pastusa Suprema, and Sabanera (16). The majority of our fungal isolates came from the first three varieties. Cropping the same potato cultivars across regions would facilitate long-distance dispersal of seed tubers infested by mycelia and sclerotia because the trade of infested seed potato within Colombia allows $\leq 10 \%$ black scurf infection on tuber surfaces (33).

We also found evidence for genotype flow among populations. Among the 33 MLMGs that were shared among populations, 18 were dispersed within a range of $0.3 \mathrm{~km}$ (between fields within a county) to $60 \mathrm{~km}$ (between counties). However, 15 MLMGs were found in populations separated by at least $100 \mathrm{~km}$ and $\leq 550 \mathrm{~km}$ (between Departments). The finding of significant genotype flow indicates that selection may also contribute to the low level of

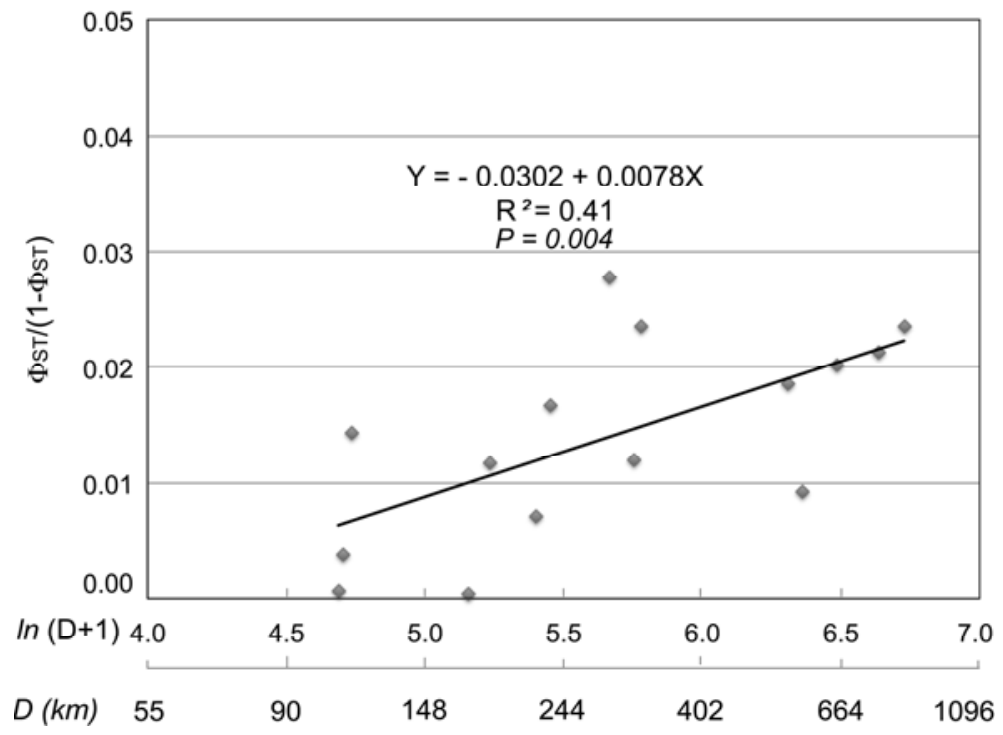

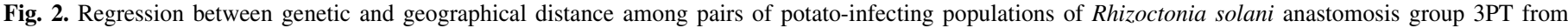

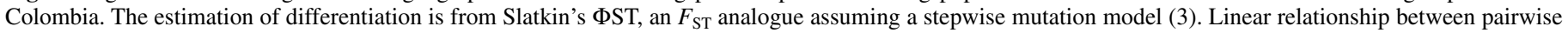
values of $\Phi S T /(1-\Phi S T)$ and the natural logarithm of geographic distances $(D+1$, in kilometers $)$ between all population pairs.

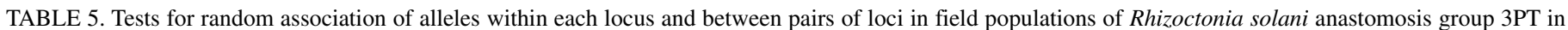
Colombia

\begin{tabular}{|c|c|c|c|c|c|c|c|c|c|}
\hline State, county & $\begin{array}{c}\text { Clone-corrected } \\
N\end{array}$ & $\begin{array}{c}\text { Loci }(N) \\
\text { under } \mathrm{HWE}^{\mathrm{v}}\end{array}$ & $F_{\mathrm{IS}^{\mathrm{W}}}$ & $P$ value $^{\mathrm{x}}$ & $I_{A}^{\mathrm{y}}$ & $\bar{r}_{\mathrm{D}}$ & $P$ value & Locus pairs ${ }^{\mathrm{z}}$ & Percent \\
\hline \multicolumn{10}{|l|}{ Cundinamarca } \\
\hline Subachoque1 & 23 & 9/11 & -0.04 & 0.64 & 1.398 & 0.144 & $<0.001$ & $9 / 55$ & 16.36 \\
\hline Subachoque2 & 12 & $10 / 10^{*}$ & 0.14 & 0.20 & 1.259 & 0.143 & $<0.001$ & $2 / 45$ & 4.44 \\
\hline Cogua1 & 21 & $7 / 11$ & 0.18 & 0.06 & 0.285 & 0.029 & 0.3100 & $1 / 55$ & 1.82 \\
\hline Cogua2 & 27 & $8 / 11$ & 0.00 & 0.49 & 1.411 & 0.143 & $<0.001$ & $14 / 55$ & 25.45 \\
\hline Sibate & 28 & $5 / 11$ & 0.06 & 0.25 & 0.331 & 0.034 & 0.0132 & $4 / 55$ & 7.27 \\
\hline \multicolumn{10}{|l|}{ Nariño } \\
\hline Pasto1 & 17 & $6 / 10^{*}$ & 0.25 & 0.02 & 0.776 & 0.088 & $<0.001$ & $0 / 45$ & 0.00 \\
\hline Pasto2 & 19 & $9 / 11$ & 0.09 & 0.20 & 0.650 & 0.067 & 0.0020 & $0 / 55$ & 0.00 \\
\hline \multicolumn{10}{|l|}{ Antioquia } \\
\hline LaUnión1 & 14 & $9 / 11$ & -0.03 & 0.56 & 1.176 & 0.123 & $<0.001$ & $3 / 55$ & 5.45 \\
\hline LaUnión2 & 28 & $8 / 11$ & -0.03 & 0.59 & 0.886 & 0.092 & $<0.001$ & $8 / 55$ & 14.55 \\
\hline \multicolumn{10}{|l|}{ Boyacá } \\
\hline Soraca1 & 18 & $8 / 11$ & 0.11 & 0.20 & 0.373 & 0.039 & 0.2650 & $0 / 51$ & 0.00 \\
\hline Soraca2 & 17 & $7 / 11$ & 0.28 & 0.01 & 0.513 & 0.052 & 0.0530 & $0 / 55$ & 0.00 \\
\hline Ventaquemada1 & 17 & $8 / 11$ & -0.03 & 0.60 & 1.003 & 0.103 & $<0.001$ & $0 / 55$ & 0.00 \\
\hline Ventaquemada2 & 15 & $11 / 11$ & -0.11 & 0.73 & 1.294 & 0.134 & $<0.001$ & $0 / 55$ & 0.00 \\
\hline \multicolumn{10}{|l|}{ Santander } \\
\hline Carcasí & 19 & $9 / 11$ & -0.05 & 0.65 & 0.796 & 0.080 & $<0.001$ & $1 / 55$ & 1.82 \\
\hline \multicolumn{10}{|l|}{ Norte de Santander } \\
\hline Chitagá & 13 & $9 / 11$ & -0.19 & 0.85 & 0.933 & 0.098 & $<0.001$ & $0 / 55$ & 0.00 \\
\hline
\end{tabular}

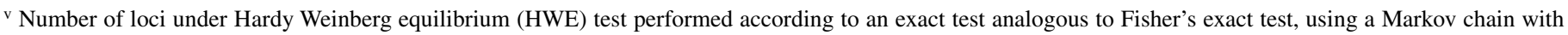
forecasted length of $10,100(30)$; indicates one monomorphic loci.

${ }^{\text {w }}$ Population-specific $F_{\mathrm{IS}}$ indices and $P$ values calculated based on 10,100 permutations using ARLEQUIN 3.11 (17).

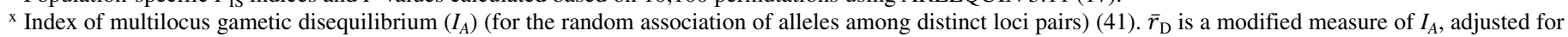
the number of loci; its values range from zero to one.

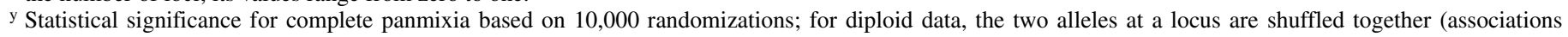
between alleles at a locus are maintained in the randomized data sets). This test is purely for associations between loci (1).

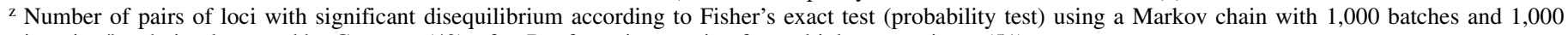
iteration/batch, implemented by Genepop (49), after Bonferroni correction for multiple comparisons (51). 
population differentiation. The extensive cropping of relatively few potato cultivars could lead to selection for host-specialized pathogen clones that could be transmitted among fields on infested seed potato. It also is possible that similar climatic conditions across the range of agroecosystems where potato are cultivated in the Colombian Andes (2,500 to 3,100 m above sea level) could have selected for climatically specialized genotypes.

Subdivision was greatest between the most geographically distant populations in Nariño and the remaining populations, with $R_{\mathrm{ST}}$ values of 0.04 to $0.11(P \leq 0.05)$. Because populations in Nariño are geographically more distant, long-distance dispersal of the fungus via seed tuber trading might have been less frequent. It also is possible that potato growers from this region have not been importing seed tubers for a long period or may have imported from a different source of seed tubers.

Though we compared populations of $R$. solani AG-3 PT from $S$. tuberosum and the local native potato $S$. phureja (61), including more populations from wild potato may have allowed us to infer a center of origin for the pathogen. However, finding areas of undisturbed wild vegetation in the Colombian Andes has become difficult because the natural landscape in these highlands has been largely converted to extensive pastures and agricultural areas. Interestingly, the native $S$. phureja potato and the $S$. tuberosum potato are infected by highly similar populations of $R$. solani AG3 PT. Given the significant gene and genotype flow that we detected, it is likely that the domesticated and wild potato plants have been colonized by the same pathogen population.

Despite the extensive regional dispersal of this tuber-borne pathogen across the Colombian Andes, from our study, we cannot assert that the Colombian populations of $R$. solani AG-3 PT are a mixture between resident and introduced populations or represent a resident population of the pathogen. Three circumstances would favor the hypothesis of a predominantly resident population: (i) historical records indicated that potato domestication and smallscale potato cropping occurred locally in the Andean region long before the arrival of the European conquistadors in South America in the early 16 th century $(44,50)$, (ii) current potato cultivation is based largely on relatively few locally bred potato cultivars (16, 22,61 ), and (iii) external introductions of seed-potato in Colombia are expected to be rare $(16,33)$. Under such circumstances, the signal of diversity and allelic richness associated with a resident population of the pathogen would persist locally. However, testing the hypothesis of a resident population would require extensive sampling of $R$. solani AG-3 from major potato-production areas to contrast the allele diversity observed in Colombia with other populations worldwide.

We also tested the hypothesis that the potato-infecting populations of $R$. solani AG-3PT are recombining, as has been shown for populations from the southern United States (11). The finding of high genotypic diversity coupled with high proportions of loci in HWE and gametic equilibrium indicate that most populations of $R$. solani AG-3PT in Colombian potato fields are recombining. $F_{\text {IS }}$ values suggested that Pasto1 and Soraca2 have experienced some inbreeding. Asexual reproduction also made a significant contribution to population structure in every field, with a clonal fraction averaging $17 \%$ and some clones being widely distributed among populations. These findings of a mixed reproductive system are consistent with an "epidemic population structure", originally described for bacteria (41) but later extended to fungi (60). Analyses of the population genetic structure of the rice- and soybean-infecting pathogen $R$. solani AG-1 IA sampled over a large geographic scale also indicated a reproductive mode varying from strictly recombining to a mixed reproductive system, in which there are recombination events followed by clonal expansion during the growing season $(6,12,53)$.

In conclusion, our study indicated that the population genetic structure of $R$. solani AG-3PT from the Colombian Andes has been shaped by human-mediated gene and genotype flow and by a mixed reproductive system in which recombination events are followed by clonal multiplication and dispersal of a few welladapted clones. Local populations are characterized by high gene and genotypic diversity and a relatively low clonal fraction. There was evidence for weak geographical differentiation among the most distant populations and little evidence for either host specialization or agroecosystem adaptation. The high gene and genotypic diversity combined with evidence for a mixed reproductive mode coupled with high gene and genotype flow among populations are characteristics of pathogens with high evolutionary potential $(42,64)$. Pathogens with high evolutionary potential require special attention when formulating management strategies. In this case, over-reliance on fungicide applications should be avoided, especially considering that thifluzamide, the fungicide used in Colombia for the management of this disease (34), belongs to a group with medium to high risk of resistance (24). Given our current knowledge, it appears likely that fungicideresistant strains could be rapidly disseminated across Colombia after they emerge.

\section{ACKNOWLEDGMENTS}

This research was supported by Universidad Nacional de Colombia, Ministerio de Agricultura y Desarrollo Rural de Colombia (MADR), Asociación Hortifrutícola de Colombia (Asohofrucol), and ETH Zurich (Swiss Federal Institute of Technology, Zurich, Switzerland). This work was partially funded by an ETH grant (TH-16/06-1) to P. C. Ceresini and a MADR-Asohofrucol grant to R. L. Ferrucho. P. C. Ceresini is a Research Fellow Pq2 from CNPq (Conselho Nacional de Desenvolvimento Cientifico e Tecnológico, Brazil, grants 308394/2009-7 and 307361/20128). R. L. Ferrucho and P. C. Ceresini contributed equally to this article. Populations collected in Cundinamarca, Antioquia, and Nariño were genotyped at the Genetic Diversity Center of ETH. We thank M. Zala (ETH Zurich) for his excellent technical assistance.

\section{LITERATURE CITED}

1. Agapow, P. M., and Burt, A. 2001. Indices of multilocus linkage disequilibrium. Mol. Ecol. Notes 1:101-102.

2. Agrios, G. N. 2005. Plant Pathology, 5th. ed. Elsevier Academic Press, Burlington, MA

3. Ames, M., and Spooner, D. M. 2008. DNA from herbarium specimens settles a controversy about origins of the European potato. Am. J. Bot. 95:252-257.

4. Balali, G. R., Neate, S. M., Kasalkheh, A. M., Stodart, B. J., Melanson, D. L., and Scott, E. S. 2007. Intraspecific variation of Rhizoctonia solani AG 3 isolates recovered from potato fields in Central Iran and South Australia. Mycopathologia 163:105-115.

5. Banville, G. J., Carling, D. E., and Ostysko, B. E. 1996. Rhizoctonia disease on potato. Pages 321-330 in: Rhizoctonia Species: Taxonomy, Molecular Biology, Ecology, Pathology, and Disease Control. Kluwer Academic Publishers, Dordrecht, The Netherlands.

6. Bernardes-de-Assis, J., Storari, M., Zala, M., Wang, W., Jiang, D., ShiDong, L., Jin, M., McDonald, B. A., and Ceresini, P. C. 2009. Genetic structure of populations of the rice-infecting pathogen Rhizoctonia solani AG-1 IA from China. Phytopathology 99:1090-1099.

7. Brush, S., Kesseli, R., Ortega, R., Cisneros, P., Zimmerer, K., and Quiros, C. 1995. Potato diversity in the Andean center of crop domestication. Conserv. Biol. 9:1189-1198.

8. Buritica, C. P. E. 1975. Fuentes de resistencia en papa (Solanum tuberosum L.) a Rhizoctonia solani Khun. Rev. ICA 10:446.

9. Ceresini, P. C., Shew, H. D., James, T. Y., Vilgalys, R. J., and Cubeta, M. A. 2007. Phylogeography of the solanaceae-infecting Basidiomycota fungus Rhizoctonia solani AG-3 based on sequence analysis of two nuclear DNA loci. BMC Evol. Biol. 7:163.

10. Ceresini, P. C., Shew, H. D., Vilgalys, R. J., Gale, L. R., and Cubeta, M. A. 2003. Detecting migrants in populations of Rhizoctonia solani anastomosis group 3 from potato in North Carolina using multilocus genotype probabilities. Phytopathology 93:610-615.

11. Ceresini, P. C., Shew, H. D., Vilgalys, R. J., Rosewich, U. L., and Cubeta, M. A. 2002. Genetic structure of populations of Rhizoctonia solani AG-3 on potato in eastern North Carolina. Mycologia 94:450-460.

12. Ciampi, M. B., Meyer, M. C., Costa, M. N., Jr., Zala, M., McDonald, B. A., and Ceresini, P. C. 2008. Genetic structure of populations of Rhizoctonia solani anastomosis group-1 IA from soybean in Brazil. Phyto- 
pathology 98:932-941.

13. Cubeta, M. A., and Vilgalys, R. 1997. Population biology of the Rhizoctonia solani complex. Phytopathology 87:480-484.

14. Cubeta, M. A., and Vilgalys, R. 2000. Rhizoctonia. Pages 109-116 in: Encyclopedia of Microbiology. J. Lederberg, M. Alexander, B. Bloom, D. Hopwood, R. Hull, B. Iglewski, A. Laskin, S. Oliver, M. Schaechter, and W. Summers. Academic Press, New York.

15. El Mousadik, A., and Petit, R. J. 1996. High level of genetic differentiation for allelic richness among populations of the argan tree [Argania spinosa (L.) Skeels] endemic to Morocco. Theor. Appl. Genet. 92:832-839.

16. Espinal, C. F., Martínez, H., Pinzón, N., and Barrios, C. 2006. La cadena de la papa en Colombia. Una mirada global de su estructura y dinámica 1991-2005. Observatorio Agrocadenas Colombia, ed. Ministerio de Agricultura y Desarrollo Rural, Bogotá, Colombia

17. Excoffier, L., Laval, G., and Schneider, S. 2005. Arlequin (version 3.0): an integrated software package for population genetics data analysis. Evol. Bioinf. 1:47-50.

18. Excoffier, L., Smouse, P. E., and Quattro, J. M. 1992. Analysis of molecular variance inferred from metric distances among DNA haplotypes: Application to human mitochondrial DNA restriction data. Genetics 131:479-491.

19. Ferrucho, R. L., Cifuentes Castellanos, J. M., Ceresini, P. C., and GarcíaDomínguez, C. 2012. Rhizoctonia solani AG-3PT is the major pathogen associated with potato stem canker and black scurf in Colombia. Agron. Colomb. 30:204-213

20. Ferrucho, R. L., Zala, M., Zhang, Z., Cubeta, M. A., Garcia-Dominguez, C., and Ceresini, P. C. 2009. Highly polymorphic in silico-derived microsatellite loci in the potato-infecting fungal pathogen Rhizoctonia solani anastomosis group 3 from the Colombian Andes. Mol. Ecol. Resour. 9:1013-1016.

21. Fox, R. 2006. Rhizoctonia stem and stolon canker of potato. Mycologist 20:116-117.

22. Franco-Lara, L., and Barker, H. 1999. Characterization of resistance to potato leafroll virus accumulation in Solanum phureja. Euphytica 108:137-144

23. Frank, J. A., and Leach, S. S. 1980. Comparison of tuberborne and soilborne inoculum in the Rhizoctonia disease of potato. Phytopathology 70:51-53.

24. Fungicide Resistance Action Committee (FRAC). 2012. FRAC Code List *2012: Fungicides sorted by mode of action (including FRAC code numbering). FRAC. http://www.frac.info/frac/publication/anhang/FRACCode-List2011-final.pdf

25. Garnier-Gere, P., and Dillmann, C. 1992. A computer program for testing pairwise linkage disequilibria in subdivided populations. J. Hered. 83:239-239.

26. Glaubitz, J. C. 2004. Convert: A user-friendly program to reformat diploid genotypic data for commonly used population genetic software packages. Mol. Ecol. Notes 4:309-310.

27. Gómez-Alpizar, L., Carbone, I., and Ristaino, J. B. 2007. An Andean origin of Phytophthora infestans inferred from mitochondrial and nuclear gene genealogies. Proc. Natl. Acad. Sci. USA 104:3306-3311.

28. Goudet, J. 1995. FSTAT (version 1.2): a computer program to calculate $F$ statistics. J. Hered. 86:485-486.

29. Grünwald, N. J., Goodwin, S. B., Milgroom, M. G., and Fry, W. E. 2003. Analysis of genotypic diversity data for populations of microorganisms. Phytopathology 93:738-746.

30. Guo, S. W., and Thompson, E. A. 1992. Performing the exact test of Hardy-Weinberg proportions for multiple alleles. Biometrics 48:361-372.

31. Hide, G. A., and Horrocks, J. K. 1994. Influence of stem canker (Rhizoctonia solani Kuhn) on tuber yield, tuber size, reducing sugars and crisp colour in cv. Record. Potato Res. 37:43-49.

32. Hurlbert, S. H. 1971. The non-concept of species diversity: a critique and alternative parameters. Ecology 52:577-586.

33. Instituto Colombiano Agropecuario (ICA). 2003. Resolución 2501 por la cual se establecen los requisitos específicos mínimos para la producción de semilla certificada de papa. ICA, Bogotá, Colombia,

34. Instituto Colombiano Agropecuario (ICA). 2011. Registros de venta de plaguicidas quimicos de uso agricola. http://www.ica.gov.co/Areas/ Agricola/Servicios/Regulacion-y-Control-de-Plaguicidas-Quimicos.aspx

35. Jeger, M. J., Hide, G. A., Boogert, P. H. J. F., Termorshuizen, A. J., and Baarlen, P. 1996. Pathology and control of soil-borne fungal pathogens of potato. Potato Res. 39:437-469.

36. Justesen, A. F., Yohalem, D., Bay, A., and Nicolaisen, M. 2003. Genetic diversity in potato field populations of Thanatephorus cucumeris AG-3, revealed by ITS polymorphism and RAPD markers. Mycol. Res. 107:1323-1331.
37. Ko, W. H., and Hora, F. 1971. A selective medium for the quantitative determination of Rhizoctonia solani in soil. Phytopathology 61:707-710.

38. Lees, A. K., Cullen, D. W., Sullivan, L., and Nicolson, M. J. 2002. Development of conventional and quantitative real-time PCR assays for the detection and identification of Rhizoctonia solani AG-3 in potato and soil. Plant Pathol. 51:293-302.

39. Luján, L. 1996. Historia de la papa. Rev. Papa 1:1-26.

40. Manly, B. F. J. 1991. Randomization, Bootstrap and Monte Carlo Methods in Biology. Texts in Statistical Science, 2nd ed. C. Chatfield and J. Zidek, eds. Chapman \& Hall/CRC, London.

41. Maynard Smith, J., Smith, N. H., O'Rourke, M., and Spratt, B. G. 1993. How clonal are bacteria? Proc. Natl. Acad. Sci. USA 90:4384-4388.

42. McDonald, B. A., and Linde, C. 2002. Pathogen population genetics, evolutionary potential, and durable resistance. Annu. Rev. Phytopathol. 40:349-379.

43. Meirmans, P. G., and Van Tienderen, P. H. 2004. Genotype and Genodive: Two programs for the analysis of genetic diversity of asexual organisms. Mol. Ecol. Notes 4:792-794.

44. Molano, J. 1995. Paisajes de la alta montaña ecuatorial. In: El Páramo. Ecosistema de Alta Montaña. Fundación Ecosistemas Andinos-ECOAN, Bogotá, D.C

45. Nei, M. 1978. Estimation of average heterozygosity and genetic distance from a small number of individuals. Genetics 89:583-590.

46. Ogoshi, A. 1987. Ecology and pathogenicity of anastomosis and intraspecific groups of Rhizoctonia solani Kuhn. Annu. Rev. Phytopathol. 25:125-143.

47. Ovchinnikova, A., Krylova, E., Gavrilenko, T., Smekalova, T., Zhuk, T., Knapp, S., and Spooner, D. M. 2011. Taxonomy of cultivated potatoes (Solanum section Petota: Solanaceae). Bot. J. Linn. Soc. 165:107-155.

48. Petit, R. J., El Mousadik, A., and Pons, O. 1998. Identifying populations for conservation on the basis of genetic markers. Conserv. Biol. 12:844855.

49. Raymond, M., and Rousset, F. 1995. Genepop (Version 1.2): Population genetics software for exact tests and ecumenicism. J. Hered. 86:248-249.

50. Restrepo, V. 2013. Los chibchas antes de la conquista española. Bogotá: Imprensa de la luz, 1895. http://www.banrepcultural.org/blaavirtual/ historia/chibch/chibch11a.htm

51. Rice, W. R. 1989. Analyzing tables of statistical tests. Evolution 43:223-225.

52. Romans, A. 2005. The Potato Book. Frances Lincoln Ltd., London.

53. Rosewich, U. L., Pettway, R. E., McDonald, B. A., and Kistler, H. C. 1999. High levels of gene flow and heterozygote excess characterize Rhizoctonia solani AG-1 IA (Thanatephorus cucumeris) from Texas. Fungal Genet. Biol. 28:148-159.

54. Simons, S. A., and Gilligan, C. A. 1997. Relationships between stem canker, stolon canker, black scurf (Rhizoctonia solani) and yield of potato (Solanum tuberosum) under different agronomic conditions. Plant Pathol. 46:651-658.

55. Slatkin, M. 1995. A measure of population subdivision based on microsatellite allele frequencies. Genetics 139:457-462.

56. Spooner, D. M., McLean, K., Ramsay, G., Robbin, W., and Bryan, G. J. 2005. A single domestication for potato based on multilocus amplified fragment length polymorphism genotyping. Proc. Natl. Acad. Sci. USA 102:14694-14699.

57. Stenberg, P., and Lundmark, M. S. A. 2003. MLG $_{\text {SIM }}$ : A program for detecting clones using a simulation approach. Mol. Ecol. Notes 3:329-331.

58. Stoddart, J. A. 1983. A genotypic diversity measure. J. Hered. 74:489490.

59. Stoddart, J. A., and Taylor, J. F. 1988. Genotypic diversity: Estimation and prediction in samples. Genetics 118:705-711.

60. Taylor, J., Jacobson, D., and Fisher, M. 1999. The evolution of asexual fungi: Reproduction, Speciation and Classification. Annu. Rev. Phytopathol. 37:197-246.

61. Theisen, K. 2013. World potato atlas: Colombia chapter. Lima: International Potato Center, 2006. https://research.cip.cgiar.org/confluence/ display/wpa/Colombia

62. Tsror, L. 2010. Biology, epidemiology and management of Rhizoctonia solani on potato. J. Phytopathol. 158:649-658.

63. Weir, B. S., and Cockerman, C. C. 1984. Estimating F-statistics for the analysis of population structure. Evolution 38:1358-1370.

64. Willi, Y., Frank, A., Heinzelmann, R., Kalin, A., Spalinger, L., and Ceresini, P. C. 2011. The adaptive potential of a plant pathogenic fungus, Rhizoctonia solani AG-3, under heat and fungicide stress. Genetica 139:903-908.

65. Zhan, J., Pettway, R. E., and McDonald, B. A. 2003. The global genetic structure of the wheat pathogen Mycosphaerella graminicola is characterized by high nuclear diversity, low mitochondrial diversity, regular recombination, and gene flow. Fungal Genet. Biol. 38:286-297. 